\title{
HAZARD OF INDOOR POLLUSTION INSIDE OUR HOMES - CASE STUDY IN CAIRO GOVERNORATE
}

\author{
Hewehy, M. A. I. ${ }^{(1)}$; Abdel Fattah, Packinam, A. M. ${ }^{(2)}$ \\ and Hassanin, Neama, ${ }^{(3)}$
}

1) Department of Environmental Basic Sciences, Institute of Environmental Studies \& Research, Ain Shams University 2) Department of Biochemistry, Faculty of Women for Arts, Science and Education, Ain Shams University

3) Department of Blood Banking, Doaa Hospital

\begin{abstract}
During the last three decades, many efforts have been made to protect tpopulations from harmful exposure to outdoor pollutants. However, people spend about $80-90 \%$ of their time in various indoor ambiences (i.e. homes, offices, restaurants, etc.) and the quality of indoor air is an important factor influencing human health .we measured indoor air pollutants levels in homes in Cairo-Egypt to estimate the different sources of pollutants and measured the concentration of following indoor air pollutants $\mathrm{H} 2 \mathrm{~S}, \mathrm{NO} 2, \mathrm{CO}, \mathrm{SO} 2$ and particulate in four residence areas two of them near industrial area which are Shoubra el khiema and Helwan ,the other two residence area were Heliopolis and Nasr city to use these data to estimate the health burden that is attributed to air pollution within homes, 30 sample were collected from 30 homes in each area using gas analyzer and particulate analyzer (Thermo dust meter).the analyses of the results demonstrated that there was a significant increase of $\mathrm{CO}, \mathrm{H} 2 \mathrm{~S}, \mathrm{SO} 2, \mathrm{NO} 2$ and particulate levels in industrial area with mean $\pm \mathrm{SD}$ : $6.1 \pm 8.3,0.05 \pm 0.01,0.05 \pm 0.01,0.2 \pm 0.09$ and $0.3 \pm 0.04$ respectively than nonindustrial area with mean \pm SD : $2.7 \pm 0.7,0.01 \pm 0.07,0.03 \pm 0.02,0.1 \pm 0.02$ and $0.2 \pm 0.03$ respectively with $\mathrm{p}$-value $=0.002,0.0001,0.0001,0.002$ and 0.002 respectively.
\end{abstract}

Keywords: Carbon Monoxide,Particulate matter, sulfur dioxide, Nitric Dioxide and Hydrogen sulfide 
J. Environ. Sci.

Institute of Environmental Studies and Research - Ain Shams University

\section{INTRODUCTION}

Indoor air pollution has been identified as a public health problem requiring greatly increased efforts in research and policy making (Ezzati et al 2001). It has been estimated that $90 \%$ of rural households in developing countries rely on biomass as the primary household fuel and in some parts of the world the reliance on biomass is increasing(Bruce et al 2000) When used in open fire or simple small-scale devices,

biomass fuels emit large amounts of hazardous airborne pollutants such as respirable particulates, carbon monoxide $(\mathrm{CO})$, and numerous hydrocarbons and oxygenated organics as well as chlorinated organic compounds, many of which have been linked to deleterious effects on health, in vitro and/or in vivo.

Two million child under age of five in the world die from Acute Lower Respiratory Tract Infection (Warwick and Doig, 2004).

$\mathrm{CO}$ and PM2.5 were taken as key indoor air pollutants, which are epidemiologically important indicators of IAP (WHO, 2002, 2005). These are the serious pollutants for indoor environments produced while cooking with firewood burning. Hence, PM2.5 and CO are on major focus in this study.

Indoor air quality is characterized by multiple determinants, such as physical parameters, chemical emissions and biological contaminations. It is a common belief that while indoors, one is safe from harmful pollutants. However, the scientific evidence has shown that indoor air at homes can be more seriously polluted than outdoor air of the largest and most industrialized cities (WHO, 2006; Franklin, 2007). Furthermore, people who constantly stay 
indoors, thus being chronically exposed to indoor pollution, are often the most susceptible individuals (infants, children and seniors).

A study performed in the Netherlands showed increased mortality rates due to the exposure of particles found indoors from vehicular emissions; a relative risk of 1.95 was estimated for people living within $50 \mathrm{~m}$ of a major road (or $100 \mathrm{~m}$ from a highway) (Hoek et al., 2002). Several other authors provided evidence of human indoor exposure to traffic pollutants in relation to distance from major roads or to traffic density (Heinrich et al., 2005; Janssen et al., 2003; Martuzevicius et al., 2008; Meíja et al., 2011). Thus, the actual extent of indoor pollution results from both outdoor and indoor sources, but also of other parameters such as building architecture, furniture position, etc. Undoubtedly, the "individuality" of each indoor environment implies further research difficulties for complete understanding of indoor pollution. 
J. Environ. Sci.

Institute of Environmental Studies and Research - Ain Shams University

\section{Type of indoor air pollutant Sources \& Health impacts}

\begin{tabular}{|c|c|c|}
\hline $\begin{array}{c}\text { Type of indoor air } \\
\text { pollutant }\end{array}$ & Sources & Health impacts \\
\hline PM & $\begin{array}{c}\text { Cooking stoves; fireplaces; smoking; } \\
\text { outdoor air }\end{array}$ & $\begin{array}{c}\text { Respiratory and } \\
\text { cardiovascular illnesses }\end{array}$ \\
\hline $\mathrm{SO} 2$ & Cooking stoves; fireplaces; outdoor air & $\begin{array}{l}\text { Impairment of respiratory } \\
\text { function }\end{array}$ \\
\hline NO2 & Cooking stoves; fireplaces; outdoor air & $\begin{array}{l}\text { Irritate the lungs and lower } \\
\text { resistance to respiratory } \\
\text { infection }\end{array}$ \\
\hline $\mathrm{CO}$ & $\begin{array}{l}\text { Cooking stoves; fireplaces; water } \\
\text { heater; outdoor air }\end{array}$ & $\begin{array}{l}\text { Highly toxic and fatal at a } \\
\text { conc. } 700 \mathrm{ppm}\end{array}$ \\
\hline Ozone & $\begin{array}{c}\text { Air cleaning device with high voltage; } \\
\text { outdoor air }\end{array}$ & $\begin{array}{c}\text { Asthma and allergic } \\
\text { triggers }\end{array}$ \\
\hline $\begin{array}{l}\text { VOCs (such as } \\
\text { formaldehyde, } \\
\quad \text { turpenes) }\end{array}$ & $\begin{array}{l}\text { Building materials including carpet, } \\
\text { plywood (emitformaldehyde); Paint and } \\
\text { solvents; Clothing (after dry cleaning) } \\
\text { (emits tetrachloroethylene, or other dry } \\
\text { cleaning fluids); air fresheners, incense, } \\
\text { other scented items; certain plants (emit } \\
\text { turpenes) }\end{array}$ & $\begin{array}{l}\text { Some are carcinogenic; can } \\
\text { also trigger the formation } \\
\text { of photochemical oxidants, } \\
\text { such as peroxyacyl nitrates } \\
\text { (PAN) and aldehydes, } \\
\text { which cause eye irritation }\end{array}$ \\
\hline Radon & $\begin{array}{c}\text { Exuded from earth and rocks such as } \\
\text { granite and gneiss incertain locations } \\
\text { with low ventilated air and trapped } \\
\text { insidehouses }\end{array}$ & $\begin{array}{l}\text { Radioactive; leading cause } \\
\text { of lung cancer innon- } \\
\text { smokers }\end{array}$ \\
\hline $\begin{array}{l}\text { Biological air } \\
\text { pollutants } \\
\text { (gasses and } \\
\text { airborne } \\
\text { particulates) }\end{array}$ & $\begin{array}{l}\text { Pets (dander), human (dust from minute } \\
\text { skin flakes and decomposed hair), dust } \\
\text { mites (enzymes and } \mu \text { m-sized fecal } \\
\text { droppings), inhabitants (methane), wall } \\
\text { and air-duct (mold) }\end{array}$ & $\begin{array}{c}\text { Increase risk for people } \\
\text { with breathing problems, } \\
\text { such as asthma sufferers, } \\
\text { and with compromised or } \\
\text { underdeveloped immune } \\
\text { systems }\end{array}$ \\
\hline
\end{tabular}

\section{AIM THE STUDY}

To measure indoor air pollutant levels in homes

To compare between different sources of indoor air pollutant in industrial area and non-industrial areas.

To use these data to estimate of the health burden that is attributable to air pollution within homes 


\section{MATERIAL AND METHOD}

The present study was conducted in four residential areas in Cairo city namely; Helwan, Shobra Elkhiema, Heliopolis and Nasr City. comprising 30 in each of Helwan and Shobra-Elkhiema and 30 in each of Heliopolis and Nasr City.

The criteria for selection took into consideration that Helwan and Shobra-Elkhiema were considered as heavily polluted areas where main industrial and other man-made sources of air emissions exist. Heliopolis and Nasr City are considered as less polluted areas, due to the absence of major air emissions sources.

the concentration of following indoor air pollutants $\mathrm{H} 2 \mathrm{~S}, \mathrm{NO} 2, \mathrm{CO}, \mathrm{SO} 2$ and particulate in four residence areas two of them near industrial area which are Shoubra Elkhiema and Helwan, the other two residence area were Heliopolis Nasr city to use these data to estimate the health burden that is attributed to air pollution within homes, we collected 30 samples from 30 homes in each area using gas analyzer(MultiRAE lite Wireless portable multi-gas monitor) and particulate analyzer (Thermo dust meter)

\section{AIR POLLUTANTS ANALYSIS}

Sampling and analysis took place according to the methodologies documented by USEPA, 1996, WHO 1994 and Harrison 1986. 
J. Environ. Sci.

Institute of Environmental Studies and Research - Ain Shams University

\section{RESULTS}

Table(1): Concentrations of indoor different air pollutants ( gases and particulates in residences of Helwan area .

\begin{tabular}{|c|c|c|c|c|c|c|}
\hline $\begin{array}{c}\text { HOUSE } \\
\text { NO. } \\
\end{array}$ & $\begin{array}{c}\text { CO } \\
\text { PPM } \\
\end{array}$ & $\begin{array}{l}\text { H2S } \\
\text { PPM } \\
\end{array}$ & $\begin{array}{l}\text { SO2 } \\
\text { PPM } \\
\end{array}$ & $\begin{array}{l}\text { NO2 } \\
\text { PPM } \\
\end{array}$ & $\begin{array}{c}\text { Particulate } \\
\mathrm{Mg} / \mathrm{m}^{\wedge} 3 \\
\end{array}$ & Flour NO \\
\hline 1 & 5.5 & 0.07 & 0.05 & 0.104 & 0.3 & 4 \\
\hline 2 & 5 & 0.07 & 0.05 & 0.201 & 0.22 & 4 \\
\hline 3 & 4.5 & 0.04 & 0.05 & 0.187 & 0.24 & 4 \\
\hline 4 & 4.3 & 0.04 & 0.05 & 0.361 & 0.22 & 3 \\
\hline 5 & 4.8 & 0.05 & 0.06 & 0.244 & 0.25 & 4 \\
\hline 6 & 5 & 0.06 & 0.06 & 0.133 & 0.27 & 3 \\
\hline 7 & 5.6 & 0.05 & 0.04 & 0.212 & 0.23 & 3 \\
\hline 8 & 5.7 & 0.04 & 0.04 & 0.245 & 0.24 & 2 \\
\hline 9 & 4.7 & 0.04 & 0.05 & 0.125 & 0.24 & 3 \\
\hline 10 & 4.8 & 0.05 & 0.06 & 0.365 & 0.25 & 2 \\
\hline 11 & 6.6 & 0.06 & 0.07 & 0.299 & 0.37 & 4 \\
\hline 12 & 6.4 & 0.06 & 0.06 & 0.288 & 0.31 & 4 \\
\hline 13 & 5.3 & 0.05 & 0.04 & 0.253 & 0.28 & 4 \\
\hline 14 & 5.4 & 0.06 & 0.05 & 0.252 & 0.28 & 3 \\
\hline 15 & 6.1 & 0.06 & 0.05 & 0.239 & 0.3 & 1 \\
\hline 16 & 5.9 & 0.06 & 0.06 & 0.325 & 0.26 & 2 \\
\hline 17 & 5.5 & 0.06 & 0.04 & 0.324 & 0.25 & 2 \\
\hline 18 & 6 & 0.06 & 0.04 & 0.201 & 0.27 & 4 \\
\hline 19 & 5.5 & 0.05 & 0.05 & 0.197 & 0.25 & 4 \\
\hline 20 & 4.4 & 0.05 & 0.05 & 0.181 & 0.24 & 3 \\
\hline 21 & 6.8 & 0.06 & 0.07 & 0.384 & 0.35 & 3 \\
\hline 22 & 6.5 & 0.06 & 0.07 & 0.253 & 0.3 & 3 \\
\hline 22 & 4.6 & 0.04 & 0.04 & 0.232 & 0.21 & 4 \\
\hline 23 & 4.7 & 0.04 & 0.05 & 0.355 & 0.25 & 4 \\
\hline 24 & 5.7 & 0.05 & 0.06 & 0.135 & 0.27 & 5 \\
\hline 25 & 5.8 & 0.05 & 0.06 & 0.375 & 0.26 & 5 \\
\hline 26 & 4.6 & 0.04 & 0.04 & 0.359 & 0.2 & 1 \\
\hline 27 & 4.4 & 0.04 & 0.04 & 0.258 & 0.25 & 1 \\
\hline 28 & 5.3 & 0.04 & 0.06 & 0.253 & 0.19 & 1 \\
\hline 29 & 5.4 & 0.05 & 0.05 & 0.352 & 0.27 & 1 \\
\hline 30 & 5.1 & 0.05 & 0.06 & 0.239 & 0.18 & 1 \\
\hline
\end{tabular}


Table(2): Concentrations of indoor different air pollutants (gases and particulates) in residences of Shobra Elkhiema area.

\begin{tabular}{|c|c|c|c|c|c|c|}
\hline $\begin{array}{c}\text { HOUSE } \\
\text { NO }\end{array}$ & $\begin{array}{c}\text { CO } \\
\text { PPM }\end{array}$ & $\begin{array}{l}\text { H2S } \\
\text { PPM }\end{array}$ & $\begin{array}{l}\text { SO2 } \\
\text { PPM }\end{array}$ & $\begin{array}{l}\text { NO2 } \\
\text { PPM }\end{array}$ & $\begin{array}{c}\text { Particulate } \\
\mathrm{Mg} / \mathbf{m}^{\wedge} 3\end{array}$ & Flour \\
\hline 1 & 4.5 & 0.01 & 0.04 & 0.265 & 0.25 & 4 \\
\hline 2 & 3.5 & 0.02 & 0.04 & 0.255 & 0.27 & 3 \\
\hline 3 & 4.3 & 0.03 & 0.05 & 0.15 & 0.28 & 4 \\
\hline 4 & 4.4 & 0.02 & 0.05 & 0.122 & 0.29 & 4 \\
\hline 5 & 3.7 & 0.04 & 0.045 & 0.155 & 0.24 & 3 \\
\hline 6 & 3.3 & 0.03 & 0.04 & 0.12 & 0.34 & 3 \\
\hline 7 & 5.3 & 0.07 & 0.05 & 0.163 & 0.3 & 5 \\
\hline 8 & 4.5 & 0.06 & 0.05 & 0.254 & 0.28 & 2 \\
\hline 9 & 4.2 & 0.05 & 0.08 & 0.145 & 0.23 & 4 \\
\hline 10 & 4 & 0.05 & 0.09 & 0.254 & 0.32 & 4 \\
\hline 11 & 3.9 & 0.05 & 0.06 & 0.257 & 0.23 & 2 \\
\hline 12 & 3.5 & 0.04 & 0.05 & 0.144 & 0.24 & 2 \\
\hline 13 & 3.7 & 0.04 & 0.05 & 0.278 & 0.21 & 2 \\
\hline 14 & 3.5 & 0.04 & 0.04 & 0.154 & 0.31 & 2 \\
\hline 15 & 4.9 & 0.04 & 0.08 & 0.165 & 0.25 & 1 \\
\hline 16 & 3.9 & 0.04 & 0.06 & 0.0255 & 0.22 & 1 \\
\hline 17 & 4.5 & 0.05 & 0.06 & 0.15 & 0.21 & 3 \\
\hline 18 & 4.7 & 0.06 & 0.05 & 0.222 & 0.22 & 3 \\
\hline 19 & 6 & 0.04 & 0.05 & 0.155 & 0.25 & 5 \\
\hline 20 & 6.5 & 0.05 & 0.05 & 0.138 & 0.27 & 5 \\
\hline 21 & 5.5 & 0.07 & 0.05 & 0.24 & 0.25 & 4 \\
\hline 22 & 6 & 0.08 & 0.06 & 0.25 & 0.19 & 5 \\
\hline 22 & 4.5 & 0.05 & 0.04 & 0.16 & 0.2 & 3 \\
\hline 23 & 4.8 & 0.06 & 0.05 & 0.278 & 0.21 & 3 \\
\hline 24 & 3.8 & 0.05 & 0.05 & 0.145 & 0.25 & 2 \\
\hline 25 & 4.4 & 0.06 & 0.05 & 0.112 & 0.23 & 2 \\
\hline 26 & 69 & 0.05 & 0.06 & 0.223 & 0.35 & 1 \\
\hline 27 & 6.5 & 0.05 & 0.05 & 0.124 & 0.27 & 1 \\
\hline 28 & 6.3 & 0.04 & 0.04 & 0.157 & 0.28 & 5 \\
\hline 29 & 6.6 & 0.05 & 0.06 & 0.332 & 0.22 & 5 \\
\hline 30 & 4.5 & 0.01 & 0.04 & 0.265 & 0.25 & 4 \\
\hline
\end{tabular}


J. Environ. Sci.

Institute of Environmental Studies and Research - Ain Shams University

Table(3): Concentrations of indoor different air pollutants(gases and particulates ) in residences of Heliopolis City area

\begin{tabular}{|c|c|c|c|c|c|c|}
\hline $\begin{array}{c}\text { HOUSE } \\
\text { NO } \\
\end{array}$ & $\begin{array}{c}\mathrm{CO} \\
\mathrm{PPM} \\
\end{array}$ & $\begin{array}{l}\text { H2S } \\
\text { PPM } \\
\end{array}$ & $\begin{array}{l}\text { SO2 } \\
\text { PPM }\end{array}$ & $\begin{array}{l}\text { NO2 } \\
\text { PPM } \\
\end{array}$ & $\begin{array}{c}\text { Particulate } \\
\mathrm{Mg} / \mathrm{m}^{\wedge} 3\end{array}$ & Flour NO \\
\hline 1 & 2.5 & N.D & 0.04 & 0.004 & 0.13 & 4 \\
\hline 2 & 3 & 0.07 & 0.05 & 0.002 & 0.13 & 4 \\
\hline 3 & 3.5 & 0.04 & 0.06 & 0.281 & 0.2 & 4 \\
\hline 4 & 3.3 & 0.03 & 0.07 & 0.065 & 0.18 & 4 \\
\hline 5 & 2.8 & 0.02 & 0.03 & 0.035 & 0.13 & 2 \\
\hline 6 & 2 & 0.02 & 0.02 & 0.089 & 0.19 & 2 \\
\hline 7 & 2.6 & 0.03 & 0.03 & 0.057 & 0.16 & 3 \\
\hline 8 & 2.7 & N.D & 0.04 & 0.06 & 0.14 & 2 \\
\hline 9 & 3.7 & 0.03 & 0.05 & 0.125 & 0.2 & 4 \\
\hline 10 & 3.8 & 0.04 & 0.06 & 0.15 & 0.2 & 4 \\
\hline 11 & 1.6 & N.D & N.D & 0.159 & 0.13 & 2 \\
\hline 12 & 1.9 & N.D & 0.02 & 0.188 & 0.16 & 1 \\
\hline 13 & 2.3 & 0.03 & 0.03 & 0.153 & 0.18 & 2 \\
\hline 14 & 2.4 & 0.04 & 0.03 & 0.052 & 0.14 & 4 \\
\hline 15 & 2.1 & N.D & 0.02 & 0.139 & 0.16 & 2 \\
\hline 16 & 2.9 & 0.03 & 0.03 & 0.125 & 0.18 & 3 \\
\hline 17 & 2.5 & 0.03 & 0.03 & 0.024 & 0.13 & 1 \\
\hline 18 & 2 & 0.03 & 0.02 & 0.101 & 0.17 & 2 \\
\hline 19 & 3.5 & 0.04 & 0.03 & 0.67 & 0.14 & 5 \\
\hline 20 & 3.4 & 0.04 & 0.02 & 0.81 & 0.14 & 5 \\
\hline 21 & 3.8 & 0.05 & 0.01 & 0.84 & 0.16 & 4 \\
\hline 22 & 3.5 & N.D & 0.03 & 0.053 & 0.17 & 1 \\
\hline 22 & 3.6 & 0.03 & 0.03 & 0.032 & 0.19 & 2 \\
\hline 23 & 3.7 & 0.04 & 0.02 & 0.55 & 0.19 & 3 \\
\hline 24 & 2.7 & N.D & 0.03 & 0.135 & 0.13 & 2 \\
\hline 25 & 2.8 & 0.01 & 0.05 & 0.175 & 0.18 & 3 \\
\hline 26 & 2.6 & N.D & 0.04 & 0.159 & 0.13 & 2 \\
\hline 27 & 2.4 & N.D & 0.04 & 0.158 & 0.12 & 3 \\
\hline 28 & 3.3 & 0.04 & 0.02 & 0.153 & 0.17 & 2 \\
\hline 29 & 3.4 & 0.03 & 0.03 & 0.052 & 0.18 & 4 \\
\hline 30 & 2.5 & N.D & 0.04 & 0.004 & 0.13 & 4 \\
\hline
\end{tabular}


Table(4): represents concentrations of different indoor air pollutants (gases and particulates) in residences of Nasr City area

\begin{tabular}{|c|c|c|c|c|c|c|}
\hline $\begin{array}{c}\text { HOUSE } \\
\text { NO }\end{array}$ & $\begin{array}{c}\text { CO } \\
\text { PPM }\end{array}$ & $\begin{array}{l}\text { H2S } \\
\text { PPM }\end{array}$ & $\begin{array}{l}\text { SO2 } \\
\text { PPM } \\
\end{array}$ & $\begin{array}{l}\text { NO2 } \\
\text { PPM }\end{array}$ & $\begin{array}{c}\text { Particulate } \\
\mathrm{Mg} / \mathbf{m}^{\wedge} \mathbf{3}\end{array}$ & $\begin{array}{c}\text { Flour } \\
\text { NO }\end{array}$ \\
\hline 1 & 1.3 & Not Detected & 0.01 & 0.035 & 0.12 & 5 \\
\hline 2 & 2.5 & Not Detected & 0.01 & 0.025 & 0.14 & 2 \\
\hline 3 & 2.2 & Not Detected & Not Detected & 0.05 & 0.11 & 1 \\
\hline 4 & 2.4 & Not Detected & 0.01 & 0.02 & 0.09 & 1 \\
\hline 5 & 2.6 & Not Detected & 0.02 & 0.05 & 0.1 & 2 \\
\hline 6 & 2.1 & Not Detected & 0.01 & 0.02 & 0.13 & 2 \\
\hline 7 & 1.8 & Not Detected & 0.01 & 0.03 & 0.17 & 4 \\
\hline 8 & 1.6 & Not Detected & Not Detected & 0.04 & 0.16 & 2 \\
\hline 9 & 2.3 & Not Detected & Not Detected & 0.045 & 0.12 & 2 \\
\hline 10 & 3.2 & Not Detected & 0.01 & 0.054 & 0.14 & 4 \\
\hline 11 & 2.5 & Not Detected & 0.03 & 0.057 & 0.11 & 1 \\
\hline 12 & 1.7 & Not Detected & 0.01 & 0.044 & 0.15 & 1 \\
\hline 13 & 1.6 & Not Detected & 0.02 & 0.078 & 0.19 & 2 \\
\hline 14 & 1.9 & 0.01 & 0.01 & 0.054 & 0.13 & 1 \\
\hline 15 & 2.1 & 0.01 & 0.01 & 0.065 & 0.17 & 1 \\
\hline 16 & 2.9 & 0.01 & 0.04 & 0.055 & 0.11 & 4 \\
\hline 17 & 2.5 & 0.01 & 0.02 & 0.105 & 0.14 & 2 \\
\hline 18 & 2.7 & 0.02 & 0.04 & 0.122 & 0.13 & 3 \\
\hline 19 & 3 & 0.03 & 0.05 & 0.05 & 0.15 & 4 \\
\hline 20 & 2.5 & 0.02 & 0.05 & 0.048 & 0.15 & 2 \\
\hline 21 & 2.5 & N.D. & 0.02 & 0.041 & 0.13 & 2 \\
\hline 22 & 2.5 & N.D. & N.D & 0.15 & 0.12 & 2 \\
\hline 22 & 3.5 & N.D. & 0.03 & 0.006 & 0.13 & 5 \\
\hline 23 & 3.8 & N.D. & 0.01 & 0.8 & 0.15 & 5 \\
\hline 24 & 3.8 & 0.02 & 0.03 & 0.15 & 0.14 & 5 \\
\hline 25 & 3.4 & 0.01 & 0.03 & 0.12 & 0.14 & 4 \\
\hline 26 & 2.2 & 0.03 & N.D & 0.13 & 0.14 & 2 \\
\hline 27 & 2.1 & 0.04 & N.D & 0.1 & 0.12 & 2 \\
\hline 28 & 3.3 & 0.03 & 0.02 & 0.17 & 0.13 & 5 \\
\hline 29 & 3.2 & N.D. & 0.01 & 0.032 & 0.16 & 5 \\
\hline 30 & 1.3 & Not Detected & 0.01 & 0.035 & 0.12 & 5 \\
\hline
\end{tabular}

Table (5): Comparison between four locations regarding kind of gas. 
J. Environ. Sci.

Institute of Environmental Studies and Research - Ain Shams University

\begin{tabular}{|c|c|c|c|c|c|c|}
\hline Gas & & heliopolis & Helwan & Nasr city & $\begin{array}{c}\text { Shobra } \\
\text { el khiema }\end{array}$ & $\begin{array}{c}\text { P } \\
\text { value }\end{array}$ \\
\hline \hline \multirow{2}{*}{ CO } & $\begin{array}{c}\text { Mean } \pm \\
\text { SD }\end{array}$ & $2.9 \pm 0.6$ & $5.2 \pm 1.0$ & $2.6 \pm 0.7$ & $6.9 \pm 12.0$ & \multirow{2}{*}{0.019} \\
\cline { 2 - 6 } & Range & $1.6-3.8$ & $1.3-6.8$ & $1.6-4.5$ & $3.3-69.0$ & \\
\hline \multirow{2}{*}{ H2S } & $\begin{array}{c}\text { Mean } \pm \\
\text { SD }\end{array}$ & $0.02 \pm 0.2$ & $0.05 \pm 0.01$ & $0.01 \pm 0.01$ & $0.05 \pm 0.01$ & \multirow{2}{*}{0.000} \\
\cline { 2 - 6 } & Range & $0.0-0.07$ & $0.0-0.07$ & $0.0-0.04$ & $0.02-0.08$ & \\
\hline \multirow{2}{*}{ SO2 } & $\begin{array}{c}\text { Mean } \pm \\
\text { SD }\end{array}$ & $0.03 \pm 0.02$ & $0.05 \pm 0.01$ & $0.02 \pm 0.02$ & $0.05 \pm 0.01$ & \multirow{2}{*}{0.000} \\
\cline { 2 - 6 } NO2 & Range & $0.0-0.1$ & $0.01-0.07$ & $0.0-0.05$ & $0.04-0.09$ & \\
\cline { 2 - 6 } & $\begin{array}{c}\text { Mean } \pm \\
\text { SD }\end{array}$ & $0.17 \pm 0.2$ & $0.25 \pm 0.1$ & $0.09 \pm 0.1$ & $0.18 \pm 0.1$ & \multirow{2}{*}{0.001} \\
\hline \multirow{2}{*}{ Particulate } & $\begin{array}{c}\text { Mean } \pm \\
\text { SD }\end{array}$ & $0.0-0.8$ & $0.04-0.4$ & $0.0-0.8$ & $0.03-0.3$ & \\
\cline { 2 - 6 } & Range & $0.1-0.2$ & $0.1-0.4$ & $0.1-0.3$ & $0.2-0.4$ & \multirow{2}{*}{0.000} \\
\hline
\end{tabular}

Table(6): correlation between floor number and kind of gas

\begin{tabular}{|c|c|c|}
\hline \multirow{2}{*}{} & \multicolumn{2}{|c|}{ Floor } \\
\cline { 2 - 3 } & $\mathbf{r}$ & $\mathbf{P}$ \\
\hline \hline $\mathrm{CO}$ & -0.061 & 0.511 \\
$\mathrm{H} 2 \mathrm{~S} 2$ & 0.232 & 0.011 \\
$\mathrm{NO} 2$ & 0.212 & 0.020 \\
Particulate & 0.238 & 0.009 \\
\hline
\end{tabular}




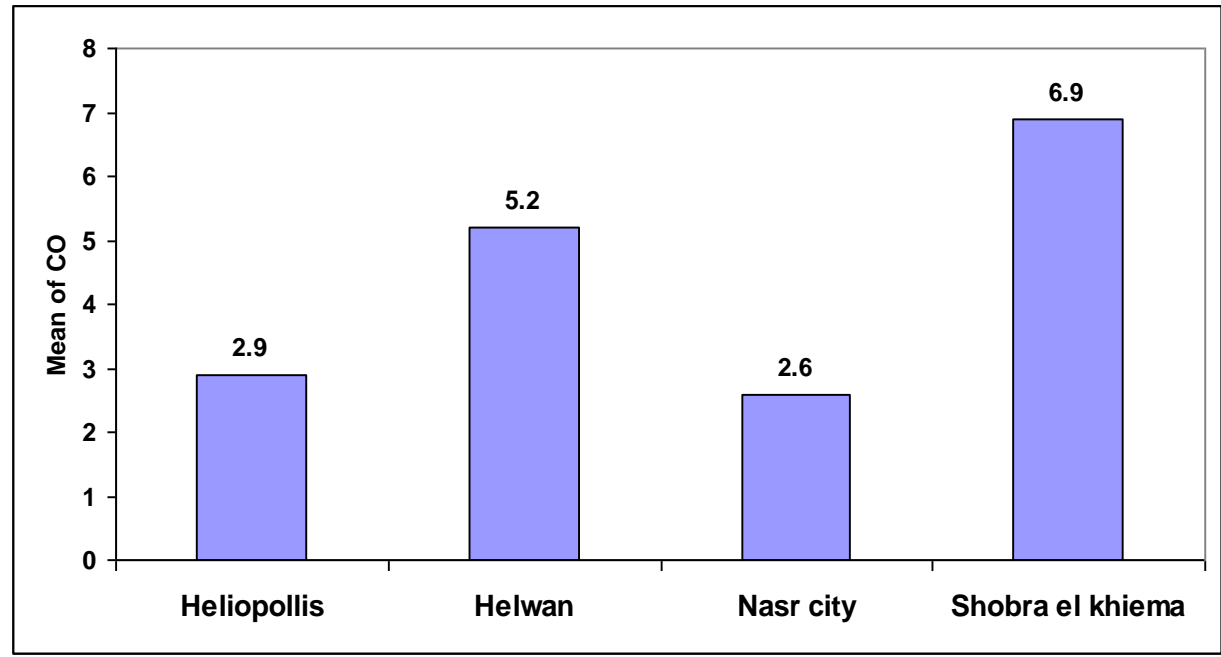

Figure (1): Comparing between four locations according to $\mathrm{CO}$.

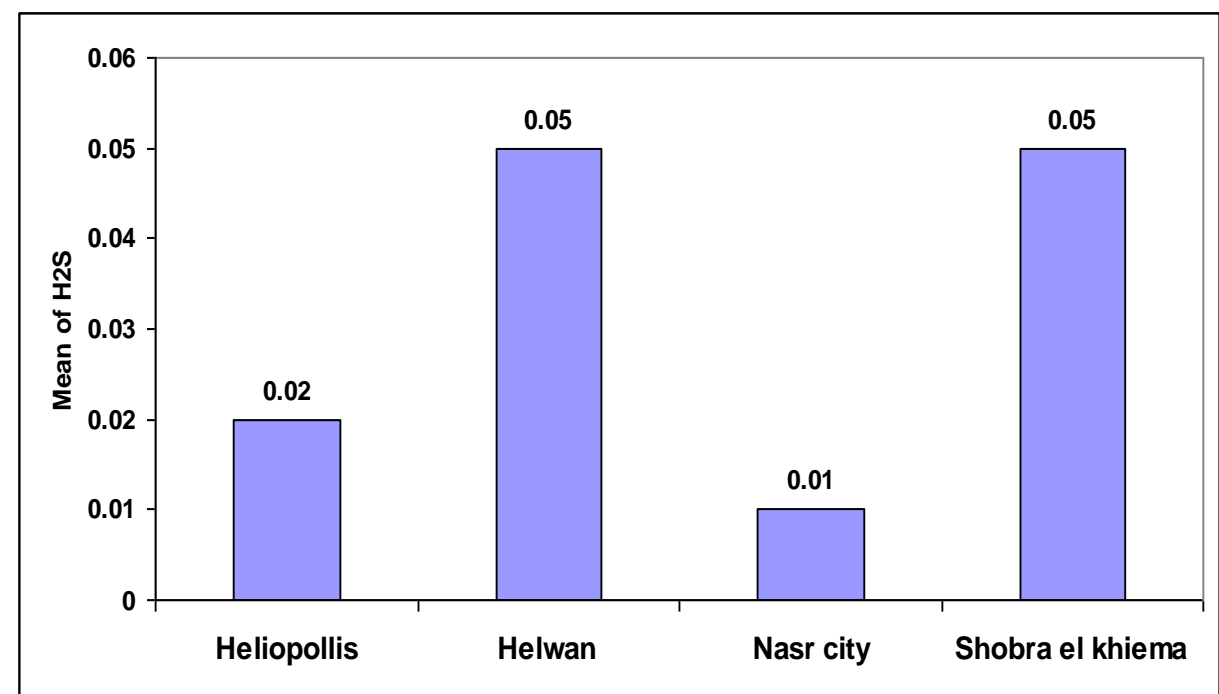

Figure (2): Comparing between four locations according to $\mathrm{H} 2 \mathrm{~S}$. 
J. Environ. Sci.

Institute of Environmental Studies and Research - Ain Shams University

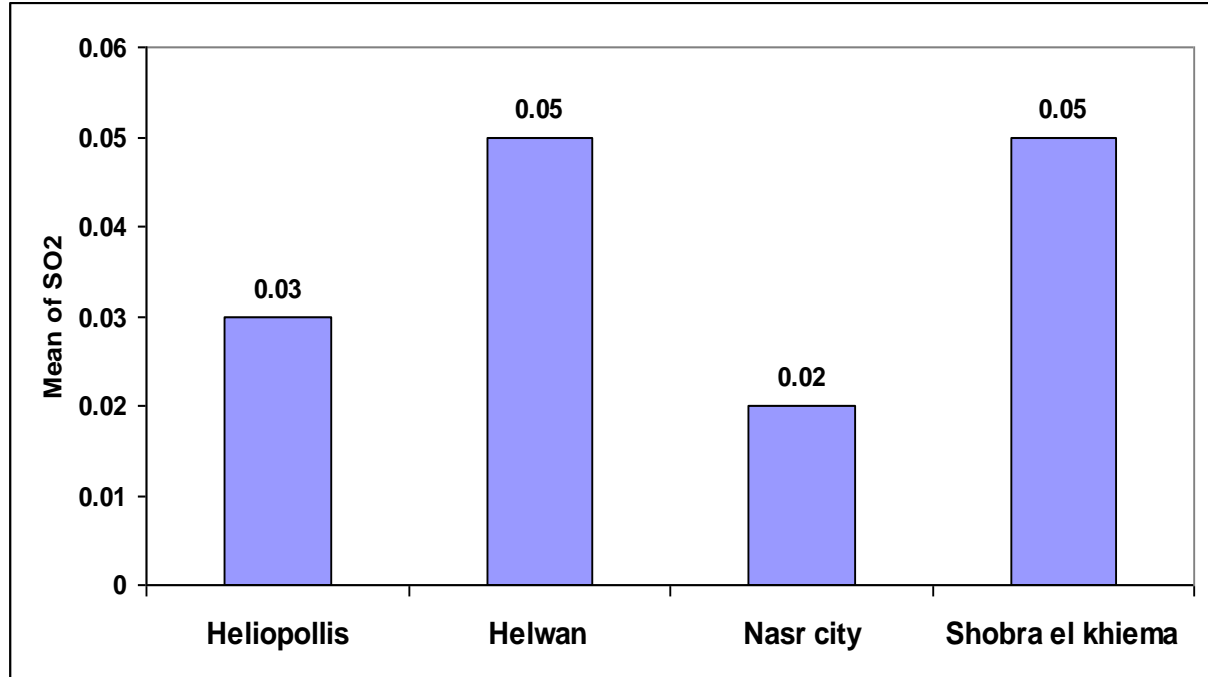

Figure(3): Comparing between four locations according to SO2.

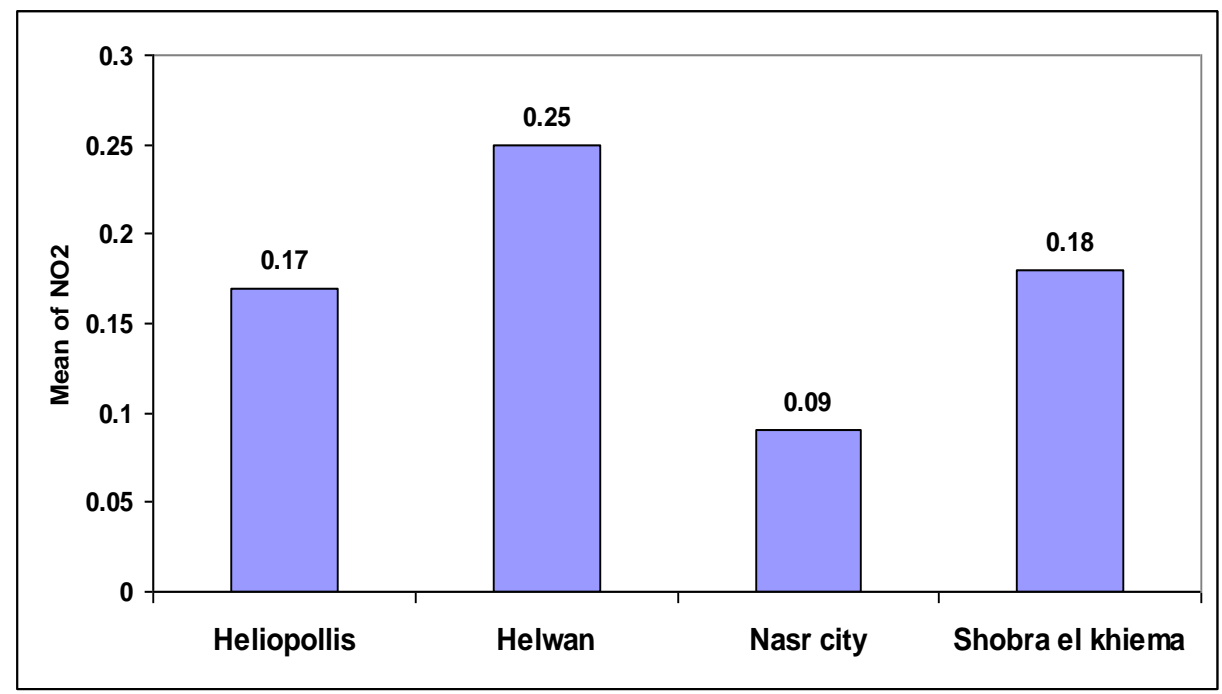

Figure(4): Comparing between four locations according to NO2. 


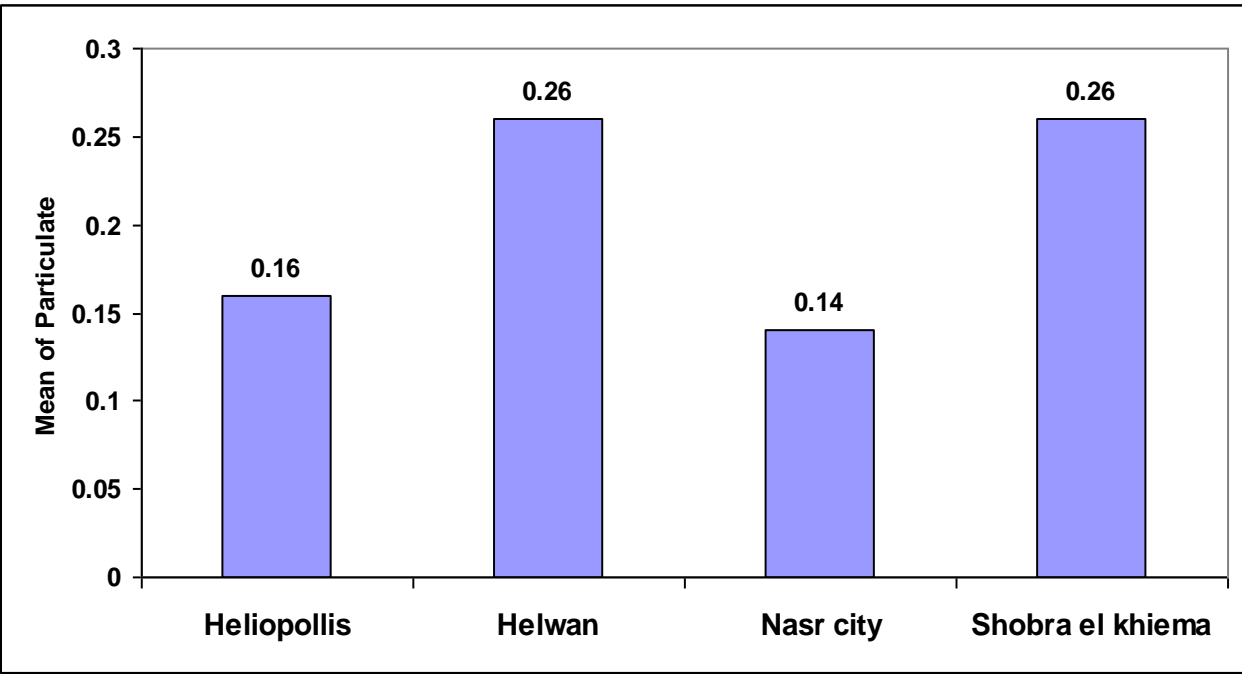

Figure (5): Comparing between four locations according to particulate

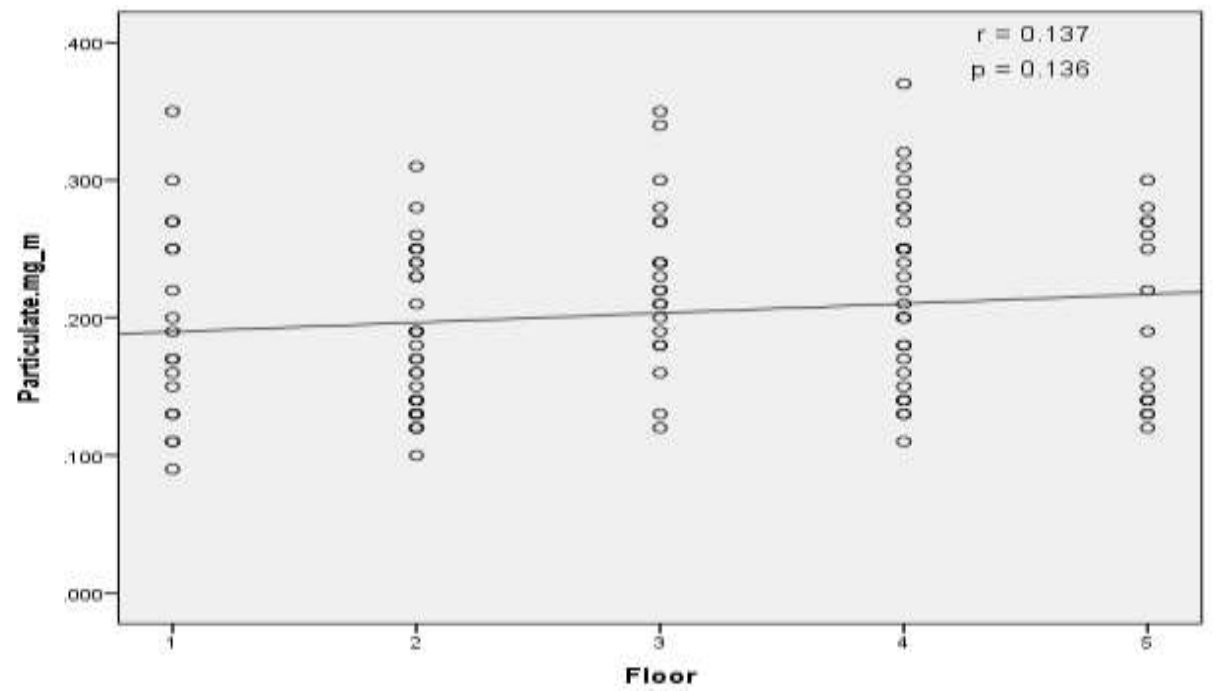

Figure(6): Correlation between floor number and particulate. 
J. Environ. Sci.

Institute of Environmental Studies and Research - Ain Shams University

Table(7): Comparison between kind of town regarding kind of gas.

\begin{tabular}{|c|c|c|c|c|}
\hline \multirow{2}{*}{ Gas } & & $\begin{array}{c}\text { Not industrial } \\
\text { (residential) }\end{array}$ & Industrial & $\begin{array}{c}\text { P } \\
\text { value }\end{array}$ \\
\hline \hline \multirow{2}{*}{$\mathrm{CO}$} & Mean \pm SD & $2.7 \pm 0.7$ & $6.1 \pm 8.3$ & \multirow{2}{*}{0.002} \\
\cline { 2 - 4 } & Range & $1.3-3.8$ & $3.3-69.0$ & \\
\hline \multirow{2}{*}{$\mathrm{H} 2 \mathrm{~S}$} & Mean \pm SD & $0.02 \pm 0.2$ & $0.05 \pm 0.01$ & \multirow{2}{*}{0.000} \\
\cline { 2 - 4 } & Range & $0.0-0.7$ & $0.01-0.08$ & \\
\hline \multirow{2}{*}{$\mathrm{SO} 2$} & Mean \pm SD & $0.03 \pm 0.02$ & $0.05 \pm 0.01$ & \multirow{2}{*}{0.000} \\
\cline { 2 - 4 } & Range & $0.0-0.07$ & $0.04-0.09$ & \\
\hline \multirow{2}{*}{$\mathrm{NO} 2$} & Mean \pm SD & $0.1 \pm 0.2$ & $0.2 \pm 0.09$ & \multirow{2}{*}{0.002} \\
\cline { 2 - 4 } & Range & $0.0-0.8$ & $0.0-0.4$ & \\
\hline \multirow{2}{*}{ Particulate } & Mean \pm SD & $0.2 \pm 0.03$ & $0.3 \pm 0.04$ & \multirow{2}{*}{0.000} \\
\cline { 2 - 4 } & Range & $0.09-0.2$ & $0.2-0.4$ & \\
\hline
\end{tabular}

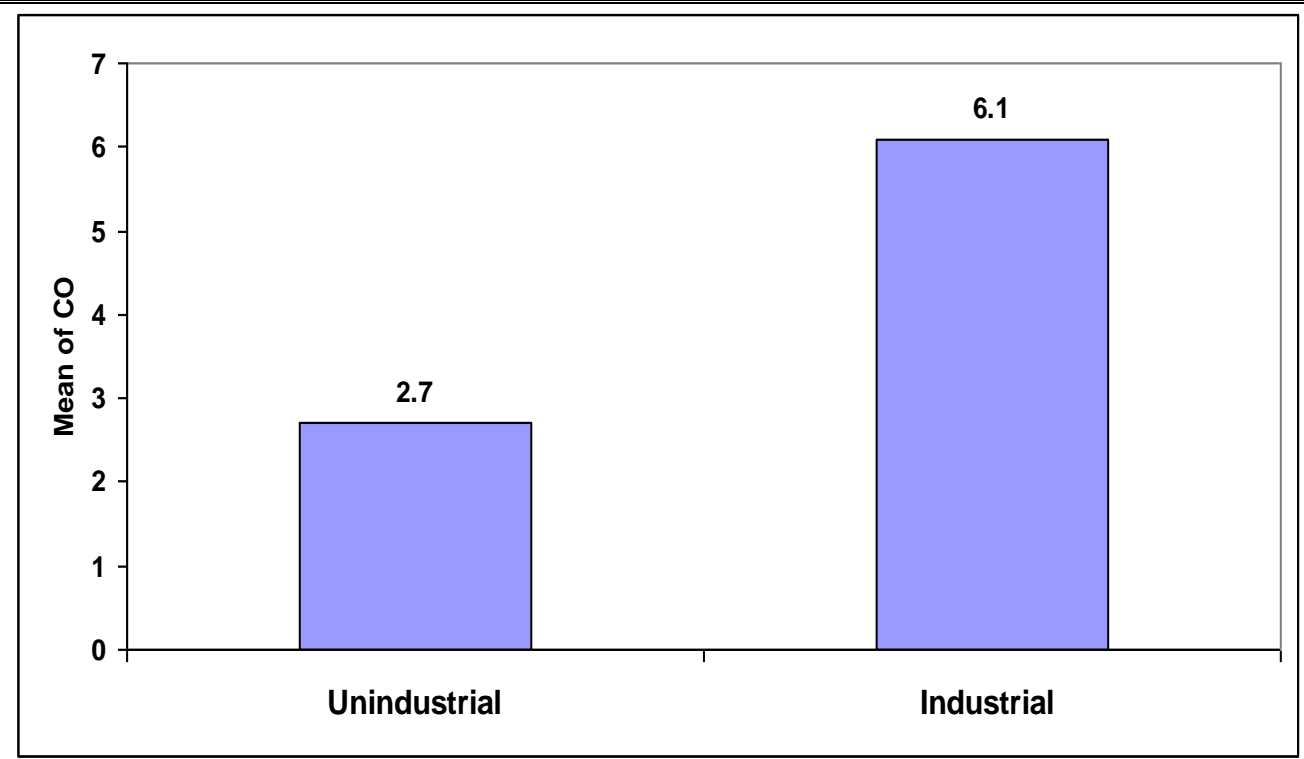

Figure(7): Comparing between type of location according to $\mathrm{CO}$ 


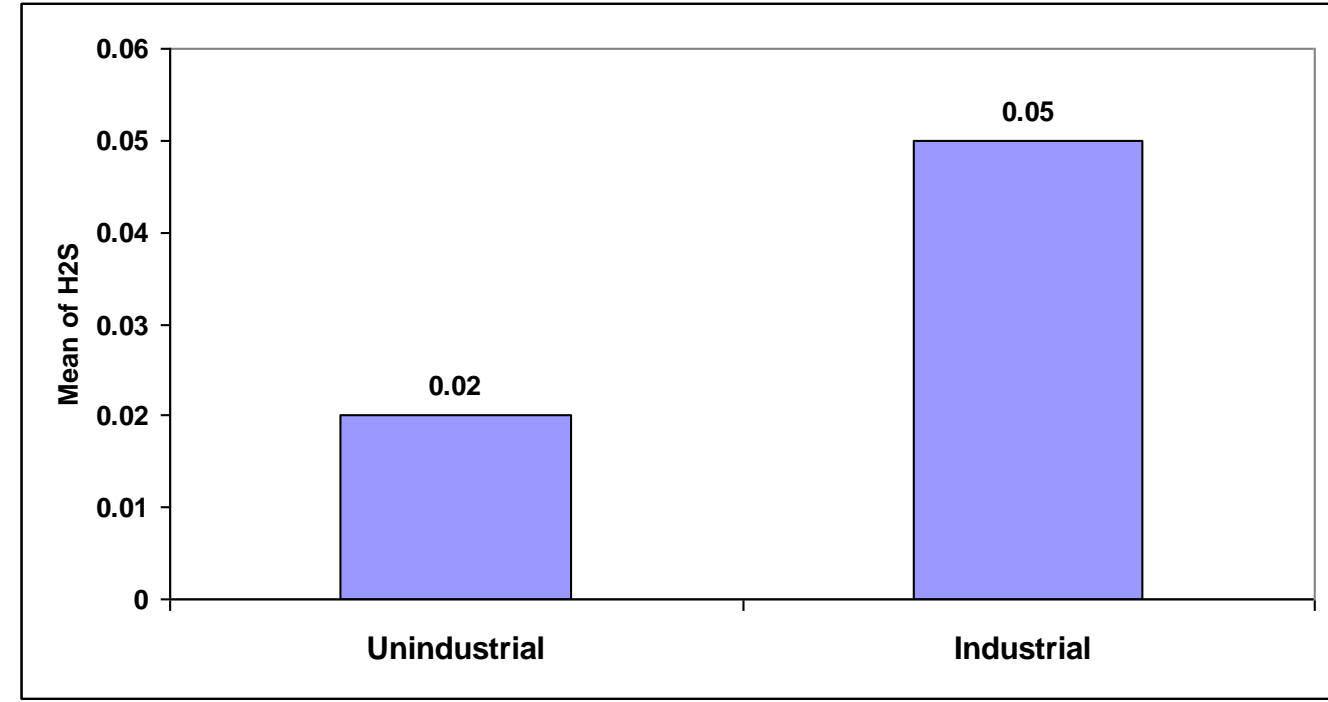

Figure(12): Comparing between type of location according to $\mathrm{H} 2 \mathrm{~S}$

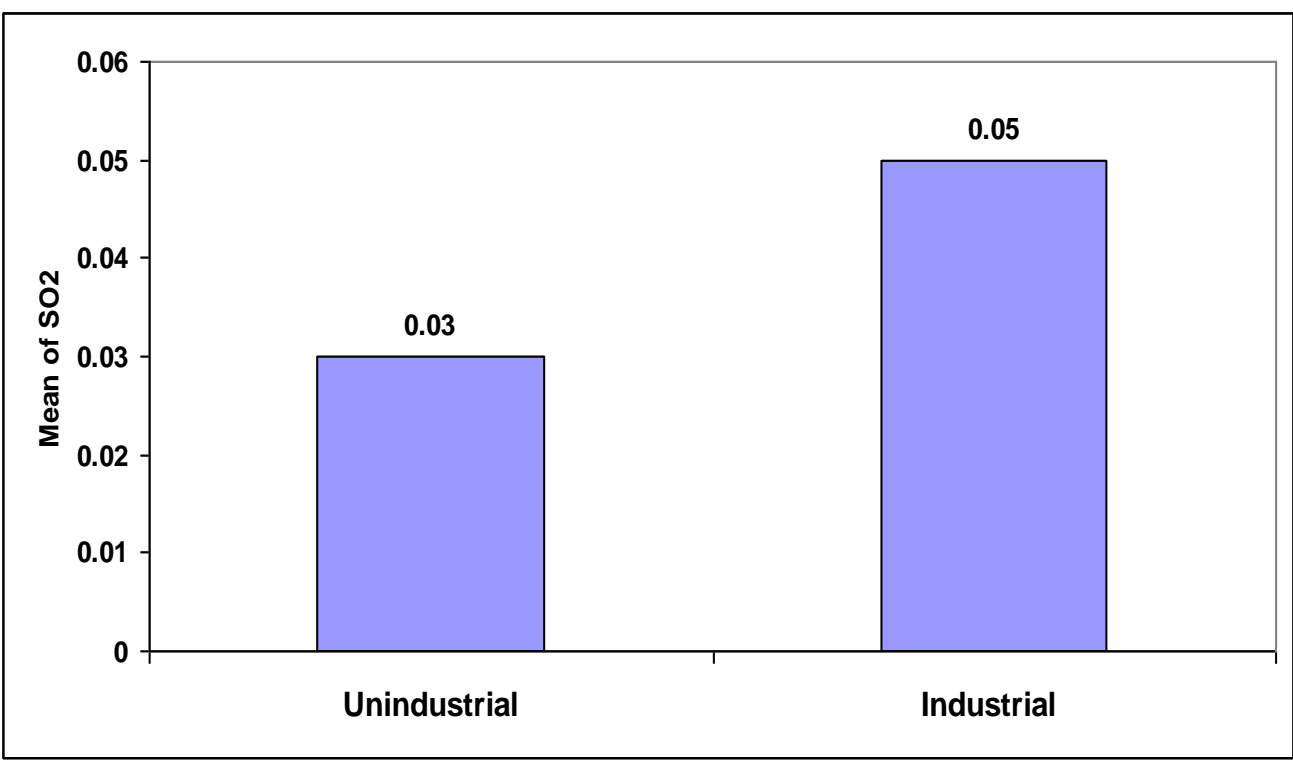

Figure (13): Comparing between types of location according to $\mathrm{SO} 2$ 
J. Environ. Sci.

Institute of Environmental Studies and Research - Ain Shams University

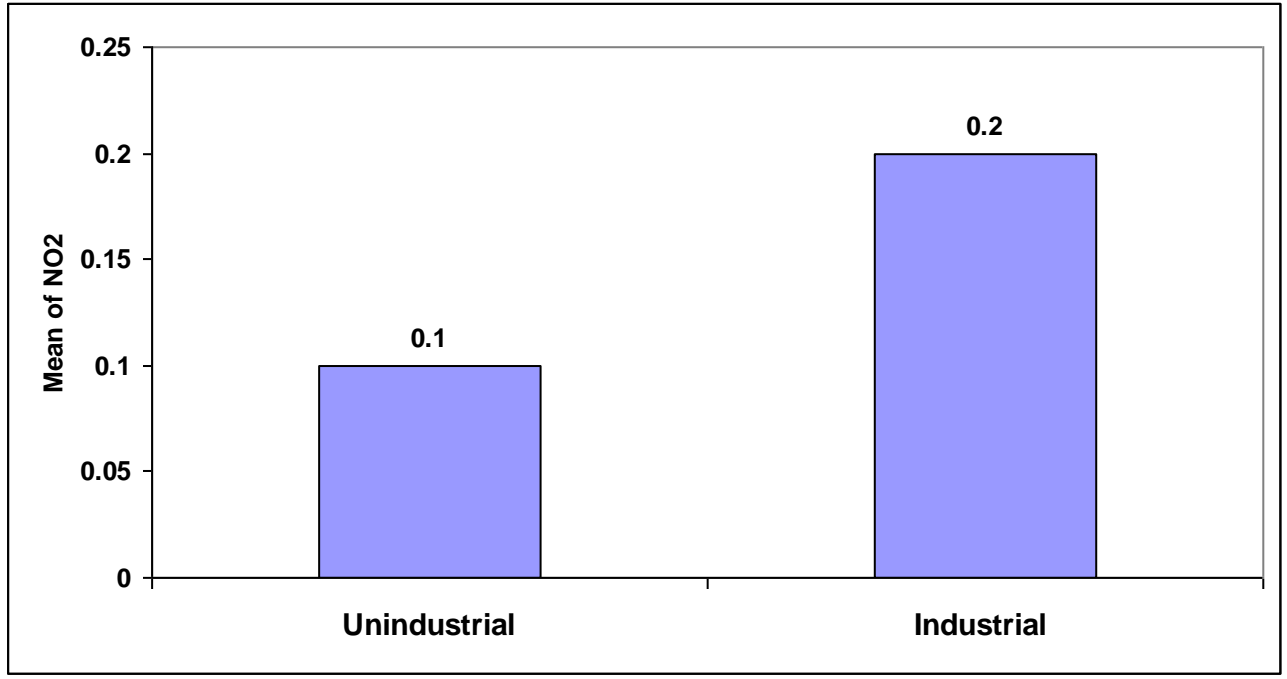

Figure(14): Comparing between type of location according to NO2

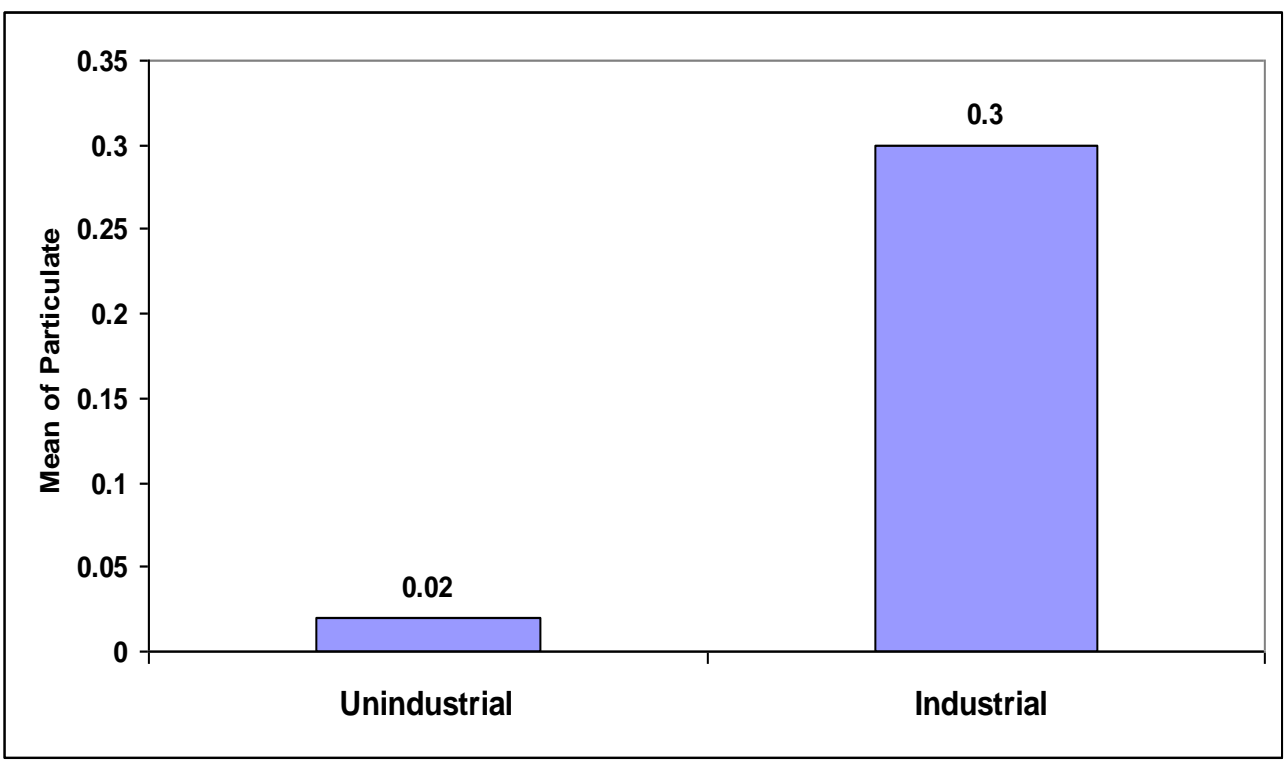

Figure(15): Comparing between type of location according to particulate 


\section{DISCUSSION}

The air we breathe contains emissions from many different sources: industry, motor vehicles, heating and commercial sources, household fuels as well as tobacco smoke. The effects of air pollution on health have been intensively studied in recent years. The results of these studies showed that air pollution harms human health and particularly is harmful for those who are already vulnerable because of their age as children and older people or existing health problems. The pidemiological evidence suggests that adverse health effects are dependent on both exposure concentrations and length of exposure, and that long-term exposures have larger, more persistent cumulative effects than short-term exposures. Exposure to PM is associated with increased hospital admissions and mortality in adults. The risk increases linearly with the concentration of pollution and there is no evidence to suggest a threshold for PM below which no adverse health effects would occur. When inhaled, PM10 particles (with a diameter of less than $10 \mu \mathrm{m}$ ) penetrate deep into the respiratory system. Finer particles (with a diameter of less than $2.5 \mu \mathrm{m}$ ) then go on to penetrate the lungs and pass into the bloodstream and are carried into other body organs. Concerned that these particles cause a wide range of health impacts, WHO has developed guidelines addressing their risks. Knowledge about the links between health and air quality has significantly advanced in the last years. It was determined that short-term exposure to PM2.5 significantly increases the risk for cardiovascular and respiratory disease among people over 65 years of age. The researchers assumed that the harmful effects may be caused by the inflammatory and oxidative effects of the black carbon particles (Suglias et al 
2008). These findings suggest additional research is needed to investigate the effects of air pollution on the development of intelligence in children and on cognitive decline for people of all ages. Human exposure to air pollution: The route of air pollutants to human organism Air pollution is a mixture of particulate matter (PM), gases, and vapor-phase molecules (Brook et al 2004). The direct rout of exposure to the air pollution is a respiratory tract. In case of dust pollutants the size of particulate matter is playing an important role in the environmental health risk. PM is categorized by aerodynamic diameter. Particles below $10 \mu \mathrm{m}$ in diameter are classified as thoracic particles PM10, particles below $2.5 \mu \mathrm{m}$ in diameter as fine particles, and particles with a diameter $<0.1 \mu \mathrm{m}$ as ultrafine particles (UFPs)(Kim, et al 1994). Particles larger than $10 \mu \mathrm{m}$ are likely to land in proximal airway, but fine particles reach the lungs and are deposited in the alveoli(Farina et al 2011). Therefore PM2.5 may be more harmful than larger ones(Pope et al 2006) Ambient fine particulate pollution was associated with increased risk of cardiovascular diseases(Terzano et al 2010 ). UFPs are deposited deeply into the lungs. The study of Terzano et al. (2010), indicates that the ultrafine particles in contrast to larger-sized particles pass into the bloodstream by different transfer routes and mechanisms and then are distributed into other body organs, including the brain with potential neurotoxic effects (Sand Strom et al 2008)Gaseous pollutants, depending on their solubility in the water, are absorbed in the proximal or the distal parts of the respiratory tract. This is important from the standpoint of the health effects. Sulfur dioxide and formaldehyde are highly water-soluble gases, therefore they do not reach the lungs, and they are 
irritating the airway epithelium of the upper respiratory tract. For example up to $98 \%$ sulfur dioxide may be absorbed in the nasopharynx during nasal breathing (the European Heart net work 2009)[. NO2 is a poorly watersoluble gas, therefore, is deposited far more peripherally in a respiratory tract compared with SO2, but does not reach the alveoli in any significant quantities ( Brook.2010)The impacts of fine particulate matter on cardiovascular health Cardiovascular disease (CVD) constitute a global problem and is the leading cause of death in the world, especially in highly developed countries. Cardiovascular disease is also a major cause of disability and of reduced quality of life (POP WHO). According to forecast, almost 20 million people will die from CVDs, mainly from heart disease and stroke by 2015 (franchni,and Mannucci PM 2007)

The results of our study show a significant increase of Co level in industrial area with mean $\pm \mathrm{SD}: 6.1 \pm 8.3$ than non-industrial area with main \pm SD : $2.7 \pm 0.7$ with $p$-value $=0.002$, a extremely statistically significant increase of $\mathrm{H} 2 \mathrm{~S}$ level in industrial area with mean $\pm \mathrm{SD}: 0.05 \pm 0.01$ than non-industrial are with mean $\pm \mathrm{SD}: 0.01 \pm 0.07$ with $\mathrm{p}$-value $=0.0001$, a significant increase of $\mathrm{SO} 2$ level in industrial area with mean $\pm \mathrm{SD}$ : $0.05 \pm 0.01$ than non-industrial area with mean $\pm \mathrm{SD}: 0.03 \pm 0.02$ with $\mathrm{p}$-value $=$ 0.0001 ,extremely significant increase of NO2 level in industrial area with mean \pm SD : $0.2 \pm 0.09$ than non-industrial area with mean \pm SD : $0.1 \pm 0.02$ with $\mathrm{p}$-value $=0.002$ and significant increase of particulate level in industrial area with mean $\pm \mathrm{SD}: 0.3 \pm 0.04$ than non-industrial area with mean $\pm \mathrm{SD}: 0.2 \pm 0.03$ with $\mathrm{p}$-value $=0.002$ 
J. Environ. Sci.

Institute of Environmental Studies and Research - Ain Shams University

\section{REFERENCES}

Bruce N, Perez-Padilla R, Albalak R(2002):. The health effects of indoor air pollution exposure in developing countries. Geneva: Worl Health Organization.

Brook RD, Rajagopalan S, Pope A, et al. (2010): Particulate Matter air Pollution and Cardiovascular Disease: An Update to the Scientific Statement From the American Heart Association. Circulation 121: 2331-2378

Bruce N, Perez-Padilla R, Albalak R(2000): Indoor air pollution in developing countries: a major environmental and public health challenge. Bulletin of the World Health Organization. ;78(9):1078-1092.

Brook R.D., Franklin B., Cascio W., Hong Y., Howard G., Lipsett M., et al. (2004):Air pollution and cardiovasclar disease: a statement for healthcare professionals from the expert panel on population and prevention science of the American Heart Association. Circulation 109:2655-71.

Ezzati M, Kammen DM(2002):. The health impacts of exposure to indoor air pollution from solid fuels in developing countries: knowledge, gaps, and data needs. Environ Health Perspect. ;110(11):10571068.

Franchini M, Mannucci PM(2007): Short-term effects of air pollution on cardiovascular diseases: outcomes and mechanisms. J ThrombHaemost;5:2169-2174

Farina F., Sancini G., Mantecca P, Gallinotti D., Camatini M., Palestini P. (2011): The acute toxic effects of particulate matter in mouse lung are related to size and season of collection. Toxicol Lett. Mar 1. [Epub ahead of print]

Kim, C.S., Fishe.r, D.M., Lutz., D.J., Gerrity, T.R., (1994): Particle deposition in bifurcating airway models with varying airway geometry. J. Aerosol. 25, 567-581 
Le Tertre A, Medina S, Samoli E, Forsberg B, Michelozzi P, Boumghar A, Vonk JM, Bellini A, Atkinson R, Ayres JG, SunyerJ,Schwartz J, Katsouyanni K. (2002): Short-term effects of particulate air pollution on cardiovascular diseases in eight European cities. $\mathbf{J}$ Epidemiol Community Health 56: 773-9

Naeher LP, Brauer M, Lipsett M, Zelikoff JT, Simpson CD, Koenig JQ, et al. .(2007): Woodsmoke health effects: a review. Inhalation toxicology; 19(1):67-106.

Pope C.A. (2007): 3rd. Mortality effects of longer term exposure to fine particulate air pollution: Review of recent epidemiological evidence. InhalToxicol., 19(Suppl. 1):33-38.

Pope C.A(2006 Dec): 3rd,Muhlestein J.B., May H.T., Renlund DG, Anderson J.L., Horne B.D. Ischemic heart disease events triggered by short-term exposure to fine particulate air pollution. Circulation. 5;114(23):2443-8. Epub 2006 Nov 13.

Sundell J. (2004): On the history of indoor air quality and health. Indoor air ;14(Suppl 7):51-58.

World Resources Institute U, UNDP(1998): World Bank, author. 1998-99 PubMed world resources: a guide to the global environment. Oxford University Press.

Smith KR. (2002): Indoor air pollution in developing countries: recommendations for research. Indoor air. ;12(3):198-207.

Schwartz J. (2001): Is there harvesting association of airborne particles with daily deaths and hospital admissions? Epidemiology; 12: 55- 61

Sandström T. (2008): Respiratory effects of air pollutants: experimental studies in humans. EurRespir J, 1995, 8, 976-995 PJ. A systematic review of the relation between long-term exposure to ambient air pllution and chronic diseases. Rev Environ Health.;23(4):243-97, 2008 o

Suglia S.F., Gryparis A.(2008): Feb Wright R.O., Schwartz J., Wright R.J..Association of black carbon with cognition among children in a prospective birth cohort study.Am J Epidemiol. 1;167(3):280-6. 
Terzano C., Di Stefano F., Conti V., Graziani E., Petroianni A.(2010 Oct): Air pollution ultrafine particles: toxicity beyond the lung. Eur Rev Med Pharmacol Sci.;14(10):809- 21.

The European Heart Network. Annual Report 2009 fighting heart disease and stroke

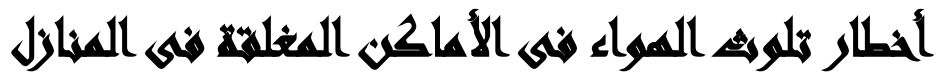

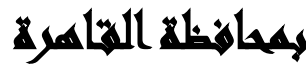

[द]

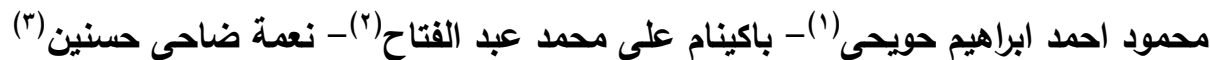

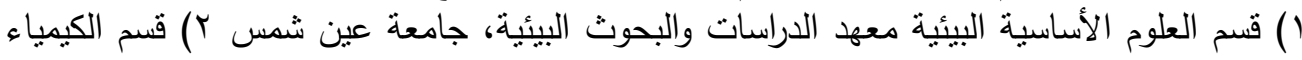

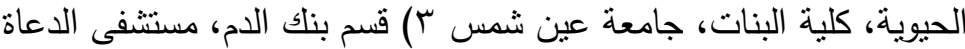

\section{المستخطي"}

خلال العقود الثلاثة الماضية ، بذلت جهود كثيرة لحماية السكان من التعرض الضار للملوثات

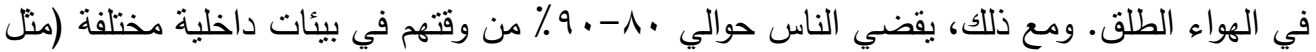

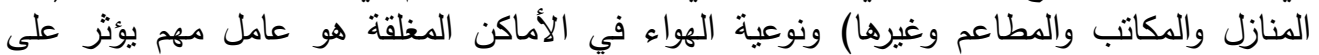
صحة الإنسان. قمنا بقياس مستويات الملوثات في الأماكن المغلقة في المنازل في القاهرة بمصر لتقانقاتير

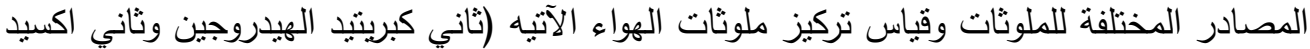

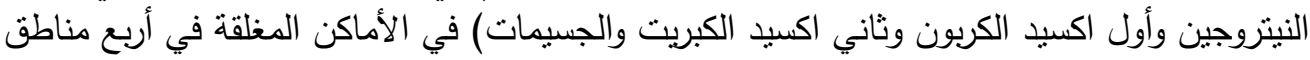

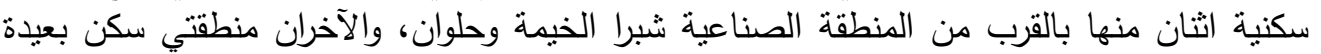

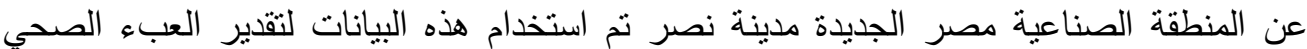

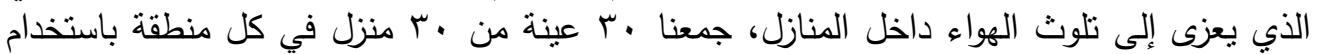

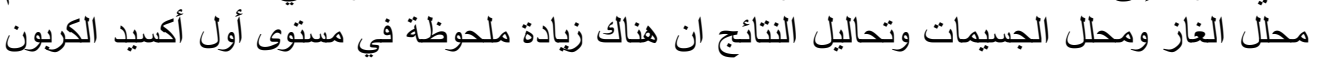

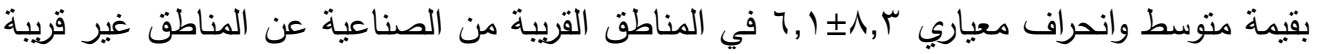

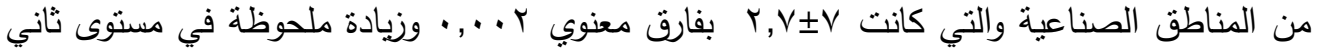

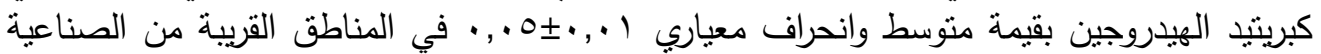

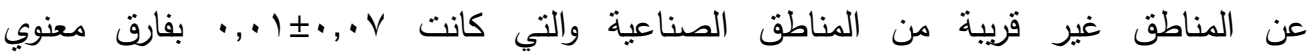

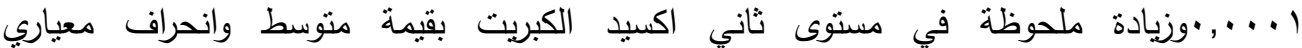

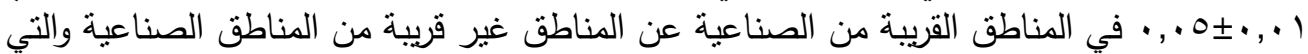




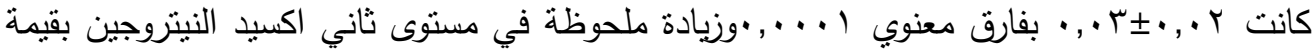

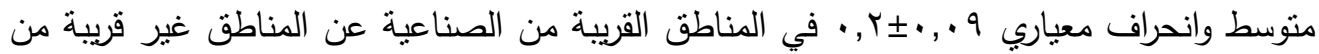

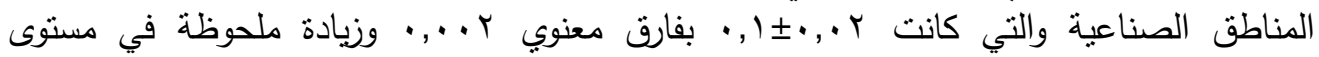

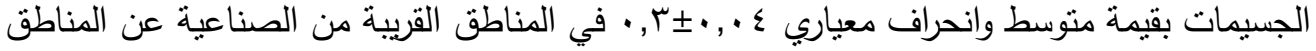

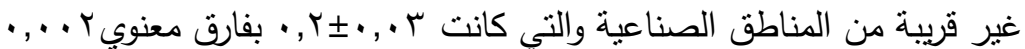

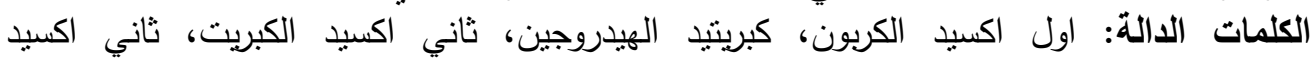

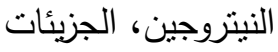

